\title{
СОСТОЯНИЕ ДИАБЕТОЛОГИЧЕСКОЙ СЛУЖБЫ В ПЕДИАТРИЧЕСКОЙ ПРАКТИКЕ РЯЗАНСКОЙ ОБЛАСТИ
}

\author{
А.Ю. Филимонова', Н.А. Белых ${ }^{2}$, С.В. Родкина ${ }^{3}$, Е.Г. Привалова ${ }^{4}$, О.Б. Борисова ${ }^{5}$, \\ Ю.В. Каширина ${ }^{6}$, К.А. Шаханова ${ }^{7}$
}

'Областная детская клиническая больнича имени Н.В. Дмитриевой, Рязанский государственный медицинский университет имени академика И.П. Павлова, Рязань

${ }^{2}$ Рязанский государственный медицинский университет имени академика И.П. Павлова, Рязань

${ }^{3}$ Скопинский межрайонный медицинский чентр, Рязанская область

${ }^{4}$ Городская детская поликлиника №1, Рязань

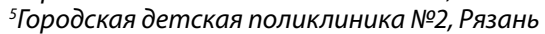

бородская детская поликлиника №6, Рязань

'Городская детская поликлиника №7, Рязань

Сахарный диабет у детей и подростков является одной из серьезных медико-социальных проблем современности. Развитию диабетологической службы уделяется повышенное внимание как на федеральном, так и на региональном уровне оказания медицинской помощи в педиатрической практике.

ЦЕЛЬ - ценить состояние организации медицинской помощи детям с сахарным диабетом в Рязанской области.

В Рязанской области в амбулаторной службе дети с сахарным диабетом наблюдаются в городских детских поликлиниках, где работают 5 врачей. Для Рязанской области в педиатрической практике характерна урбанизация эндокринологической службы -основной процент специалистов сконцентрирован в областном центре и лишь в одном из крупных районов области (Скопинском) - ведет прием детский эндокринолог, дети из остальных районов (в Рязанской области 25 районов) - пациенты наблюдаются в Консультативно- диагностическом центре Областной детской клинической больницы имени Н.В. Дмитриевой, где работают 2 специалиста.

Стационарную помощь детям с сахарным диабетом в регионе оказывают в Областной детской клинической больнице имени Н.В. Дмитриевой, где в педиатрическом многопрофильном отделении на 47 коек выделены 15 эндокринологических коек. В рамках этого отделения работают два врача - детских эндокринолога, один из которых является заведующим отделения. На базе отделения работает школа «Сахарного диабета», которая в 2020 году была модернизирована. На территории отделения выделено отдельное помещение, которое при поддержке компании «Ново Нордиск» было оснащено современной удобной мебелью, оргтехникой и наглядными материалами.

Дети с сахарным диабетом 1 типа в Рязанской области (309 пациентов на 01.01.2021 — распространенность 157 на 100000 детского населения) получают современные препараты аналоги человеческого инсулина.

С начала 2021 г. в обеспечении препаратами инсулина произошли изменения- пациенты, получавшие препарат с торговым наименованием Новорапид, переведены на аналог инсулина сверхбыстрого действия Фиасп. В назначениях инсулинов базального профиля также изменились тенденции- дети, получавшие препарат с торговым наименованием Лантус, а так же дети старше 6 лет с впервые выявленным сахарным диабетом получают препарат Туджео.

27\% детей с сахарным диабетом 1 типа находятся на помповой инсулинотерапии. С 2020 года в Рязанской области появилась возможность установки инсулиновых помп в рамках региональной ВМП (установлено 11 инсулиновых помп Медтроник 754).

Показатели гликированного гемоглобина $\left(\mathrm{HbA}_{1 c}\right)$ - средний уровень у пациентов г. Рязани 8,7\%, среди них дети, получающие помповую инсулинотерапию имеют средний уровень $\mathrm{HbA}_{1 с}-$ $7,45 \%$, у пациентов из районов области - 8,5\% и 7,3\% соответственно. 


\section{СБОРНИК ТЕЗИСОВ}

XVII Российская научно-практическая конференция детских эндокринологов «Достижения науки в практику детского эндокринолога»

32\% детей и подростков с сахарным диабетом 1 типа используют для самоконтроля непрерывный мониторинг глюкозы. С начала 2021 года в регионе 35 пациентам в рамках благотворительной помощи установлена система флеш- мониторинга Freestyle Libre.

Выводы. Учитывая современные тенденции в оценке эффективности терапии сахарного диабета- время нахождения в целевом диапазоне, уменьшение вариабельности гликемии, снижение частоты гипогликемии и достижение целевых уровней гликированного гемоглобина альянс современных препаратов инсулина, средств самоконтроля, а также повышение уровня обучения и мотивированности пациентов и их родственников в вопросах управления диабетом должно способствовать достижению максимальной эффективности терапии сахарного диабета у детей и подростков. 